\title{
Sistem Pakar Identifikasi Modalitas Belajar Siswa Dengan Implementasi Algoritma C4.5
}

\author{
Rachmawati Soewono $^{\mathrm{a}^{*}}$, Rachmat Gernowo ${ }^{\mathrm{b}}$, Priyo Sidik Sasongko ${ }^{\mathrm{c}}$ \\ ${ }^{a}$ Program Magister Sistem Informasi Universitas Diponegoro \\ ${ }^{\mathrm{b}}$ Jurusan Fisika, Fakultas Sains dan Matematika, Universitas Diponegoro \\ ${ }^{\mathrm{c}}$ Jurusan Informatika, Fakultas Sains dan Matematika, Universitas Diponegoro \\ Naskah Diterima : 13 Januari 2014; Diterima Publikasi : 14 Februari 2014
}

\begin{abstract}
C4.5 Algorithm is one of the classification technique in machine learning which is used in data mining process by build a decision tree which is represent in the rules. The aims of classification technique in data mining is to recognize the regularity of the pattern and the relation in a huge dataset by historical data collection. Students' modalities measurement which is done by the questionnaire is produce historical data which is potentially to be processed to generate the classification that can be converted in rules. The expert acquisition and the $\mathrm{C} 4.5$ algorithm classification rules are used as knowledge base in the expert system. Therefore this research is done to build an expert system of the student's modalities identification by implementing C4.5 algorithm that can produce seven categories of modalities classification, they are : visual, auditory, kinesthetic, visualauditory, visual-kinesthetic, auditory-kinesthetic and visual-auditory-kinesthetic which has good in accuracy. The accuracy of the $\mathrm{C} 4.5$ algorithm classification and the expert system testing prediction is $80 \%$.
\end{abstract}

Keywords : Expert system; Decision tree; C4.5 Algorithm; Modalities.

\begin{abstract}
Abstrak
Algoritma C4.5 merupakan salah satu teknik klasifikasi pada machine learning yang digunakan pada proses data mining dengan membentuk sebuah pohon keputusan (decision tree) yang direpresentasikan dalam bentuk aturan (rule). Teknik klasifikasi pada proses data mining bertujuan untuk menemukan keteraturan, pola dan hubungan dalam set data yang berukuran besar dengan pengumpulan data historis. Pengukuran modalitas belajar siswa yang dilakukan dengan uji kuesioner menghasilkan kumpulan data historis yang berpotensi untuk diolah dan menghasilkan klasifikasi yang dapat dikonversikan kedalam bentuk aturan. Bersamaan dengan akuisisi pengetahuan pakar, aturan yang dihasilkan melalui klasifikasi dengan algoritma C4.5 dapat digunakan sebagai basis pengetahuan pada sistem pakar. Untuk itu penelitian ini bertujuan membangun sistem pakar identifikasi modalitas belajar siswa dengan mengimplementasikan algoritma C4.5. yang dapat menghasilkan klasifikasi modalitas yang terbagi menjadi tujuh kategori, yaitu visual, auditori, kinestetik, visual-auditori, visual-kinestetik, auditori-kinestetik dan visual-auditori-kinestetik dengan tingkat keakurasian dan kecepatan yang baik. Berdasarkan pengujian hasil prediksi klasifikas pada algoritma C4.5 dan sistem pakar, keakurasian yang dihasilkan sebesar $80 \%$.
\end{abstract}

Kata Kunci : Sistem pakar; Decision tree; Algoritma C4.5; Modalitas

\section{Pendahuluan}

Modalitas belajar siswa merupakan hal yang penting untuk diidentifikasi oleh orangtua, guru dan siswa itu sendiri karena potensi keberhasilan siswa di bidang akademis didukung oleh modalitas belajar yang tepat. Modalitas belajar merupakan cara menyerap informasi melalui indera yang kita miliki (DePorter and Hernacki, 1999). Siswa yang memanfaatkan modalitas belajar dalam proses belajar mengajar memiliki kemandirian dan kepercayaan diri yang lebih (Tomuletiu et al., 2011), namun modalitas belajar siswa juga harus didukung oleh metode mengajar yang sesuai (Iurea et al., 2011).

Pengukuran modalitas yang digunakan pada umumnya adalah dengan kuesioner, baik itu secara

\footnotetext{
*) Penulis korespondensi: rahma.soewono@gmail.com
}

manual maupun secara terkomputerisasi dan menghasilkan enam jenis modalitas, yaitu visual, auditori, kinestetik, visual-auditori, visual-kinestetik dan auditori-kinestetik. Namun hasil dari pengukuran ini hanya berdasarkan jumlah ciri modalitas terbanyak tanpa ada parameter pengukuran yang menjadi acuan. Dengan demikian dibutuhkan suatu sistem sebagai alat ukur identifikasi modalitas menggunakan parameter pengukuran yang dapat dijadikan acuan dalam pengidentifikasian modalitas belajar selanjutnya.

Penelitian terkait dengan sistem pakar banyak digunakan untuk mengidentifikasi dan mendiagnosis suatu permasalahan dalam berbagai bidang, seperti identifikasi bibit gulma pada tanaman sereal atau bijibijian (Andujar et al., 2006), diagnosis penyakit ikan 
(Li et al., 2002), identifikasi jenis serangga hutan (Kaloudis et al., 2005), identifikasi bakat olahraga (Papic et al., 2009), dan identifikasi psikologis klinis (Spiegel dan Nenh, 2004).

Algoritma C4.5 (Quinlan, 1993), (Larose, 2005) telah digunakan sebagai teknik klasifikasi dengan membentuk pohon keputusan yang memiliki tingkat keakuratan, kecepatan, dan kehandalan yang lebih baik dibandingkan dengan teknik klasifikasi lainnya seperti support vector machine (SVM), naive bayes dan neural network (Wu et al., 2009). Metode pada Machine learning dan data mining pada saat ini telah dikembangkan untuk digunakan dalam membangun basis pengetahuan pada sistem pakar (Prasadl et al., 2011).

Penelitian ini bertujuan untuk membuat sistem pakar identifikasi modalitas belajar siswa dengan mengimplementasikan algoritma C4.5 dengan menggunakan lima parameter pengukuran, yaitu komunikasi, belajar, preferensi, memori, sikap dan menghasilkan tujuh kategori modalitas, yaitu visual, auditori, kinestetik, visual-auditori, visual-kinestetik, auditori-kinestetik dan visual-auditori-kinestetik.

\section{Kerangka Teori}

\subsection{Modalitas}

Modalitas adalah kombinasi dari bagaimana seseorang dapat menyerap, mengatur serta mengolah informasi (DePorter and Hernacki, 1999). Modalitas belajar yang sesuai adalah kunci keberhasilan seseorang dalam belajar dan tidak jarang menghasilkan prestasi yang baik. Prestasi belajar adalah suatu bukti keberhasilan belajar atau kemampuan seorang siswa dalam melakukan kegiatan belajarnya sesuai dengan bobot yang dicapainya (Winkel, 2007). Oleh karena itu dalam kegiatan belajar, siswa sangat perlu dibantu dan diarahkan untuk mengenali modalitas belajar yang sesuai dengan dirinya sehingga tujuan pembelajaran dapat dicapai secara efektif (Sari, 2013). Terdapat tiga jenis modalitas belajar yang digunakan siswa dalam memperoleh informasi (DePorter and Hernacki, 1999), yaitu Visual, Auditori dan Kinestetik. Namun tidak jarang ditemui siswa yang memiliki modalitas kombinasi dua diantara ketiganya atau bahkan ketiga-tiganya. Sehingga identifikasi modalitas dapat di kategorikan menjadi tujuh macam, yaitu visual, auditori, kinestetik, visual-auditori, auditori-kinestetik, visual-kinestetik dan visualauditori-kinestetik. karakteristik tiap modalitas dapat terlihat pada tabel 1 .

\subsection{Sistem Pakar}

Sistem Pakar merupakan sistem yang berusaha mengadopsi pengetahuan manusia ke dalam komputer, agar komputer dapat menyelesaikan masalah seperti yang biasa dilakukan oleh para ahli (Kusumadewi, 2003). Konsep dasar sistem pakar mengandung keahlian, ahli, pengalihan keahlian, inferensi, aturan dan kemampuan menjelaskan (Turban, 1995). Sistem pakar disusun oleh dua bagian utama, yaitu lingkungan pengembangan (development environment) dan lingkungan konsultasi (consultation environment) (Turban, 1995). Lingkungan pengembangan digunakan oleh pengembang sistem pakar (expert system builder) untuk membangun komponen dan memasukkan pengetahuan ke dalam basis pengetahuan.

Tabel 1. Karakteristik modalitas (DePorter and Hernacki, 1999)

\begin{tabular}{|c|c|c|}
\hline No. & $\begin{array}{l}\text { Gaya } \\
\text { belajar }\end{array}$ & Karakteristik \\
\hline 1. & Visual & $\begin{array}{l}\text { 1. Senanitiasa memperhatikan gerak } \\
\text { bibir seseorang yang sedang } \\
\text { berbicara kepadanya. } \\
\text { 2. Cenderung menggunakan gerakan } \\
\text { tubuh saat mengungkapkan sesuatu } \\
\text { 3. Kurang menyukai berbicara di } \\
\text { depan kelompok dan kurang } \\
\text { menyukai untuk mendengarkan } \\
\text { orang lain. } \\
\text { 4. Biasanya tidak dapat mengingat } \\
\text { informasi yang diberikan secara } \\
\text { lisan. } \\
\text { 5. Lebih menyukai peragaaan } \\
\text { daripada penjelasan lisan. } \\
\text { 6. Biasanya siswa dengan modalitas } \\
\text { belajar visual dapat duduk tenang } \\
\text { di tengah situasi yang ribut atau } \\
\text { ramai tanpa merasa terganggu. }\end{array}$ \\
\hline 2. & Auditori & $\begin{array}{l}\text { 1. Mampu mengingat dengan baik } \\
\text { materi yang didiskusikan dalam } \\
\text { kelompok } \\
\text { 2. Mengenal dan mengingat banyak } \\
\text { lagu ataupun iklan televisi. } \\
\text { 3. Suka berbicara } \\
\text { 4. Pada umumnya bukan pembaca } \\
\text { yang baik } \\
\text { 5. Kurang dapat mengingat dengan } \\
\text { baik apa yang baru saja dibacanya. } \\
\text { 6. Kurang baik dalam mengerjakan } \\
\text { tugas mengarang atau menulis. }\end{array}$ \\
\hline 3. & Kinestetik & $\begin{array}{l}\text { 1. Suka menyentuh segala sesuatu } \\
\text { yang dijumpainya. } \\
\text { 2. Sulit untuk berdiam diri. } \\
\text { 3. Suka mengerjakan segala sesuatu } \\
\text { dengan menggunakan tangan. } \\
\text { 4. Memiliki koordinasi tubuh yang } \\
\text { baik. } \\
\text { 5. Suka menggunakan objek yang } \\
\text { nyata sebagai alat bantu belajar. } \\
\text { 6. Mempelajari hal-hal yang abstrak } \\
\text { merupakan hal yang sangat sulit. }\end{array}$ \\
\hline
\end{tabular}

Lingkungan konsultasi digunakan oleh nonpakar untuk memperoleh pengetahuan dan nasihat pakar. Komponen-komponen sistem pakar dalam dua bagian tersebut dapat dilihat pada gambar 1 . 


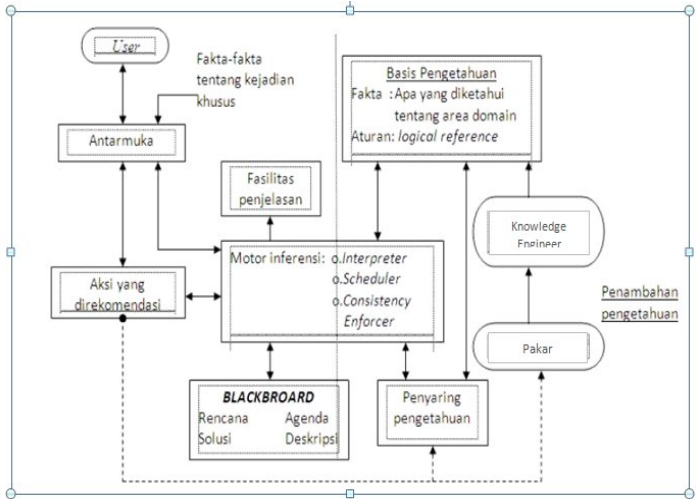

Gambar 1. Arsitektur struktur sistem pakar (Turban, 1995)

Komponen yang terdapat dalam sistem pakar adalah antarmuka pengguna (user interface) yang merupakan mekanisme yang digunakan untuk pengguna dan sistem pakar untuk berkomunikasi, basis pengetahuan (knowledge base) mengandung pengetahuan untuk pemahaman, formulasi dan penyelesaian masalah, akuisisi pengetahuan (knowledge acqusition) merupakan transformasi keahlian dalam menyelesaikan masalah dari sumber pengetahuan ke dalam program komputer, mesin inferensi (inference engine) mekanisme pola pikir dan penalaran yang digunakan oleh pakar dalam menyelesaikan suatu masalah, wilayah kerja (workplace atau blackboard) merupakan area kerja memori yang disimpan sebagai basis data untuk deskripsi persoalan terbaru yang ditetapkan oleh data input, fasilitas penjelasan dan perbaikan pengetahuan (Turban, 1995).

\subsection{Algoritma $C 4.5$}

Algoritma C4.5 merupakan salah satu algoritma yang digunakan dalam penyelesaian masalah pada metode pohon keputusan (decision tree) yang merupakan teknik klasifikasi pada data mining. Secara umum teknik klasifikasi dalam data mining di kelompokkan menjadi beberapa kelompok seperti yang ditunjukkan pada gambar 2. Metode pohon keputusan (decision tree) merupakan metode yang merubah fakta yang sangat besar menjadi sebuah pohon keputusan yang mereprentasikan aturan-aturan (Quinlan, 1993). Data dalam pohon keputusan biasanya dinyatakan dalam bentuk tabel dengan atribut dan record.

Atribut menyatakan suatu parameter yang disebut sebagai kriteria dalam pembentukan pohon. Salah satu atribut merupakan atribut yang menyatakan data solusi per-item data yang disebut dengan target atribut. Setiap atribut memiliki nilai yang dinamakan dengan instance. Tabel keputusan dapat dilihat pada tabel 2. Tabel keputusan efektif digunakan bilamana kondisi yang akan diseleksi di dalam program jumlahnya cukup banyak dan rumit.

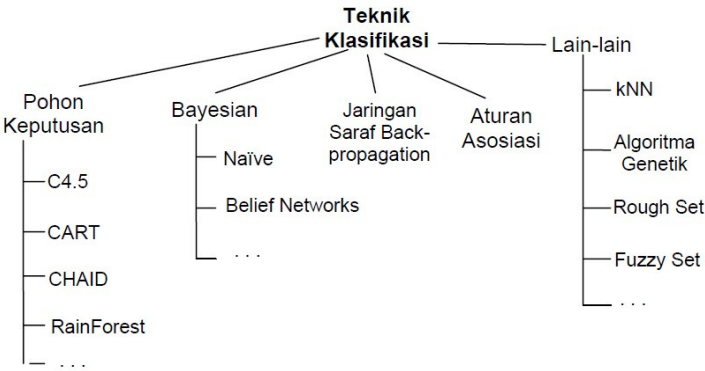

Gambar 2. Pengelompokan Teknik Klasifikasi Data mining (Moertini, 2005)

Tabel 2. Tabel keputusan

\begin{tabular}{|c|c|c|c|c|c|c|}
\hline Siswa & Komunikasi & Belajar & Preferensi & memori & Sikap & Modalitas \\
\hline 1 & Visual & Visual & Kinestetik & Visual & Visual & Visual \\
\hline 2 & Visual & Visual & Visual & Visual & Visual & Visual \\
\hline 3 & Visual & Auditori & Auditori & Auditori & Auditori & Auditori \\
\hline 4 & Kinestetik & Auditori & Auditori & Auditori & Auditori & Auditori \\
\hline 5 & Visual & Auditori & Auditori & Auditori & Auditori & Auditori \\
\hline 6 & Auditori & Auditori & Auditori & Auditori & Auditori & Auditori \\
\hline 7 & Auditori & Auditori & Visual & Auditori & Visual & Visual - Auditori \\
\hline 8 & Kinestetik & Visual & Visual & Visual & Visual & Visual \\
\hline 9 & Kinestetik & Visual & Kinestetik & Visual & Visual & Visual-Kinestetik \\
\hline 10 & Kinestetik & Kinestetik & Auditori & Auditori & Kinestetik & Auditori - Kinestetik \\
\hline
\end{tabular}

Algortima C4.5 menggunakan information gain untuk memilih atribut yang akan digunakan untuk pemisahan objek (Raditya, 2012). Atribut yang mempunyai information gain paling tinggi akan dijadikan akar atau node. Information gain adalah ukuran efektifitas suatu atribut dalam mengklasifikasikan data (Suyanto, 2009). Nilai entropy didapatkan dengan rumus sebagai berikut :

$\operatorname{Gam}(S, A)=\operatorname{Entropy}(S) \sum_{i=1}^{n}|S i| \mid \operatorname{sintropy}(S i)$

dimana nilai Entropy didapatkan dengan rumus sebagai berikut :

Entropy $(s)=\left(-\left(p_{+} \log _{2} p_{+}\right)\right)+\left(-\left(p_{-} \log _{2} p_{-}\right)\right)$

dan nilai $\mathrm{p}$ didapatkan dengan rumus :

$p=\frac{\| S i \mid}{\|s\|}$

sehingga didapatkan nilai Entropy sebagai berikut :

Entropy $(S)=\sum_{i=1}^{n}-p_{i} \log _{2} p_{i}$

Keterangan :

$S \quad$ : Himpunan kasus

A : Atribut

$n \quad$ : Jumlah partisi atribut $S$

$p_{+} \quad:$ : Proporsi bernilai mendukung

$p_{-} \quad$ : Proporsi bernilai tidak mendukung

$p_{i} \quad:$ Proporsi ke- $i$

$\left|S_{i}\right| \quad$ : Jumlah kasus ke- $i$

$|S| \quad$ : Jumlah kasus ke $S$ 


\section{Metodologi}

Dalam pengembangan sistem pakar identifikasi modalitas belajar siswa terdapat tahapan-tahapan yang dilaksanakan untuk menghasilkan hasil yang maksimal. Tahapan-tahapan tersebut terdiri dari identifikasi, konseptualisasi, formalisasi, implementasi dan pengujian. Tahapan pengembangan sistem dapat dilihat melalui blog diagram yang terdapat pada gambar 3 .

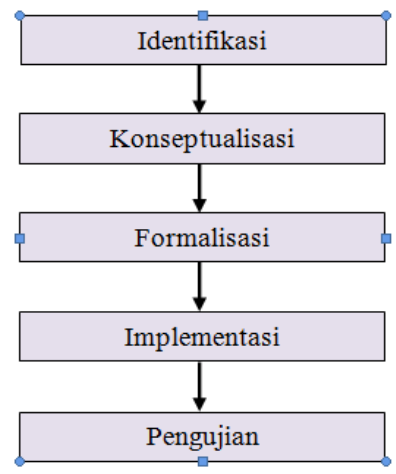

Gambar 3. Blog Diagram Tahapan Pengembangan Sistem Pakar (Firebaugh, 1989)

Pada tahap awal dimulai dengan identifikasi data yaitu pengumpulan data historis yang merupakan data-data hasil uji modalitas belajar siswa yang telah diujikan kepada siswa. Kemudian melakukan pencarian pola pertanyaan yang menghasilkan lima parameter yang digunakan sebagai alat ukur penentuan modalitas, yaitu komunikasi, belajar, preferensi, memori dan sikap.

Data yang diidentifikasi dalam penelitian ini kemudian dianalisis kembali oleh beberapa pakar psikologi pendidikan melalui wawancara. Hasil wawancara ini digunakan sebagai validasi data historis yang dikumpulkan yang kemudian digunakan sebagai akuisisi pengetahuan dalam sistem pakar.

Tahapan formalisasi merupakan tahapan perancangan sistem pakar yang terdiri dari analisis desain fungsi, perancangan basis pengetahuan, perancangan mesin inferensi dan perancangan antarmuka. Pada perancangan basis pengetahuan ini, proses pembentukan pohon keputusan yang menghasilkan aturan dan klasifikasi dilakukan dengan mengimplementasikan algoritma C4.5. Proses pembentukan aturan dan klasifikasi ini dapat terlihat melalui diagram alir pengklasifikasian dengan pohon keputusan pada gambar 4 .

Setelah proses yang dilakukan algoritma C4.5 untuk menghasilkan pohon keputusan modalitas belajar siswa telah selesai terbentuk maka didapatkan hasil berupa klasifikasi dan aturan yang digunakan pada sistem pakar. Pohon keputusan modalitas belajar siswa dapat terlihat pada gambar 5 .

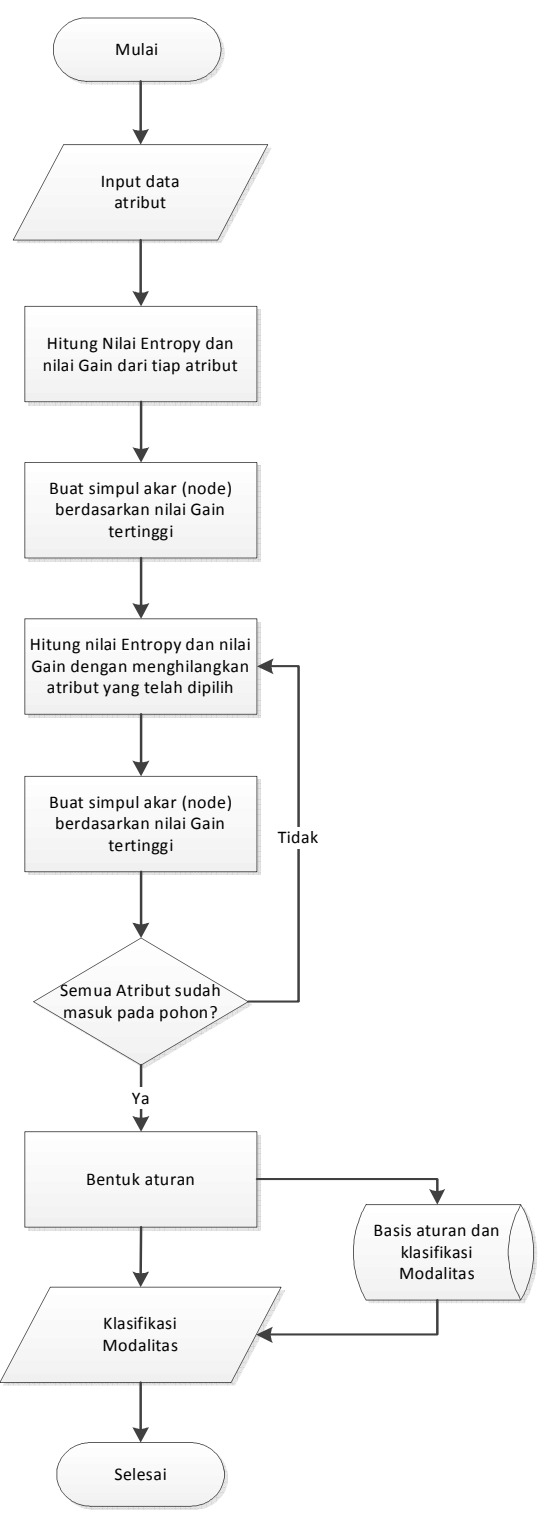

Gambar 4. Diagram alir pengklasifikasian dengan pohon keputusan

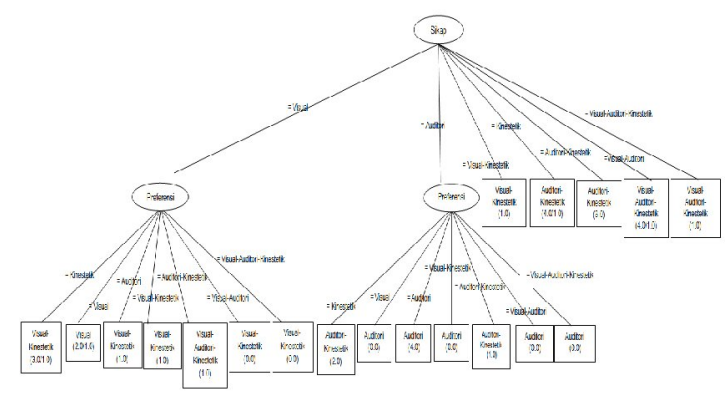

Gambar 5. Pohon keputusan modalitas belajar siswa 
Tahapan selanjutnya yaitu pengimplementasian hasil perancangan yang telah dilakukan pada tahapan sebelumnya. Dalam implementasi ini dihasilkan antarmuka Admin yang berfungsi sebagai pengelola sistem dan antarmuka Siswa untuk berinteraksi langsung pada lingkungan konsultasi sistem pakar. Kerangka sistem pakar dengan implementasi Kerangka sistem pakar dengan implementasi algoritma C4.5 dapat dilihat pada gambar 6 .

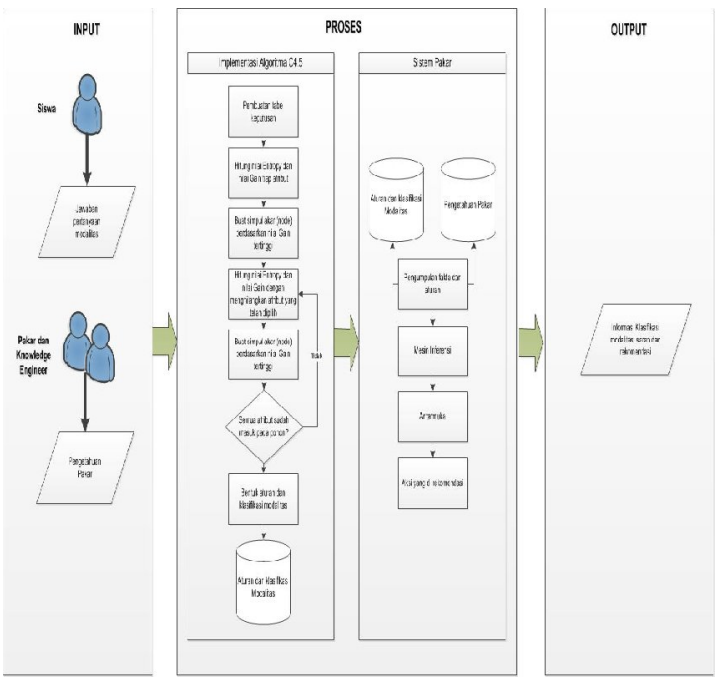

Gambar 6. Kerangka sistem pakar dengan implementasi algoritma C4.5.

Tahapan akhir yaitu pengujian sistem dilakukan untuk mencari validitas dengan membandingkan aturan klasifikasi yang dihasilkan algoritma C4.5 oleh WEKA dan sistem pakar serta mencari nilai akurasi dari klasifikasi data.

1. Validitas aturan klasifikasi pohon keputusan

Validitas aturan klasifikasi hasil pohon keputusan

Algoritma C4.5 dilakukan dengan membandingkan antara hasil aturan pohon keputusan pada sistem pakar dengan pemrograman PHP dan hasil aturan pohon keputusan pada WEKA. Proses perbandingan ini dilakukan dengan mengujicobakan 700 data yang dibagi menjadi data pelatihan (training) dan data pengujian (testing).

a. Hasil generate aturan pohon keputusan $\mathrm{C} 4.5$ dari WEKA :

J48 pruned tree

memori $=$ Visual

Preferensi $=$ Kinestetik

| | Komunikasi = Visual: Visual (7.0)

| | Komunikasi $=$ Kinestetik: Visual - Kinestetik (11.0)

$\mid$ Komunikasi $=$ Auditori: Visual - Kinestetik $(0.0)$
Preferensi $=$ Visual: Visual (73.0)

Preferensi $=$ Auditori: Visual (10.0)

memori $=$ Auditori

sikap = Visual: Visual - Auditori (14.0)

sikap $=$ Auditori

| | Preferensi = Kinestetik: Auditori - Kinestetik (9.0)

| | Preferensi $=$ Visual: Auditori (0.0)

| | Preferensi = Auditori: Auditori (52.0)

| sikap = Kinestetik: Auditori - Kinestetik (10.0)

memori $=$ Kinestetik: Kinestetik (14.0)

b. Hasil generate $\mathrm{C} 4.5$ dari aplikasi sistem pakar : memori $=$ Visual

| Preferensi $=$ Kinestetik

$\mid$ Komunikasi $=$ Visual $\quad($ Visual $=72$,

Auditori $=19$

Kinestetik $=0, \quad$ Visual-Auditori $=1$, VisualKinestetik $=0$,

Auditori-Kinestetik=0): Visual

$\mid$ Komunikasi $=$ Kinestetik

(Visual $=18$, Auditori $=16$,

Kinestetik $=2, \quad$ Visual-Auditori $=0, \quad$ Visual-

Kinestetik=11,

Auditori-Kinestetik=18) :Visual-Kinestetik

$\mid \quad$ Komunikasi $=$ Auditori (Visual $=0$,

Auditori $=17$,

Kinestetik $=12$, Visual-Auditori $=13$, Visual-

Kinestetik $=0$,

Auditori-Kinestetik=0) : Visual -Kinestetik

| Preferensi $=$ Visual $($ Visual $=73$, Auditori $=0$, Kinestetik $=0$, Visual-

Auditori $=13$, Visual-Kinestetik $=0$, Auditori-

Kinestetik=0) :

Visual

| Preferensi $=$ Auditori $($ Visual $=10$, Auditori $=52$,

Kinestetik=1,

Visual-Auditori $=1, \quad$ Visual-Kinestetik $=0$, Auditori-

Kinestetik=10): Visual

memori $=$ Auditori

sikap $=$ Visual (Visual $=90$, Auditori $=0$, Kinestetik $=0$, Visual-

Auditori $=14, \quad$ Visual-Kinestetik $=11$,

Auditori-Kinestetik=0):

Visual-Auditori

| sikap = Auditori

$\mid \quad$ Preferensi $=$ Kinestetik (Visual $=7$,

Auditori $=0$, Kinestetik=13,

Visual-Auditori $=0$, Visual-Kinestetik $=11$, Auditori-

Kinestetik=9):Auditori - Kinestetik

| | Preferensi $=$ Visual $($ Visual $=73$, Auditori $=0$, Kinestetik $=0$,

Visual-Auditori $=13$, Visual-Kinestetik $=0$,

Auditori-

Kinestetik=0):Auditori

$\mid \quad$ Preferensi $=$ Auditori $($ Visual $=10$, Auditori $=52$, Kinestetik=1, 
Auditori-

Visual-Auditori $=1, \quad$ Visual-Kinestetik $=0$,

Kinestetik=10):Auditori

sikap $=$ Kinestetik (Visual $=0$, Auditori $=0$, Kinestetik=14, Visual-

Auditori $=0$, Visual-Kinestetik $=0$, AuditoriKinestetik=10):

Auditori- Kinestetik

memori $=$ Kinestetik (Visual $=0, \quad$ Auditor $=0$, Kinestetik=14, Visual-

Auditori $=0, \quad$ Visual-Kinestetik $=0, \quad$ Auditori-

Kinestetik $=0$ ):

Kinestetik

2. Validitas nilai akurasi klasifikasi

Nilai akurasi klasifikasi didapatkan dengan mengujicobakan data menggunakan pohon keputusan yang telah terbentuk dari data pelatihan (training). Prosedur pengujian ini dilakukan dengan membagi 700 data modalitas menjadi $75 \%$ data pelatihan (525 data) dan $25 \%$ data ujicoba (175 data). Dengan menggunakan classifier output pada WEKA didapatkan hasil keakuratan sebagai berikut :

$===$ Evaluation on test split $======$ Summary $===$ Correctly Classified Instances 140

$80 \%$ Incorrectly Classified Instances $20 \%$ Kappa statistic

Mean absolute error

Root mean squared error

0.2037

Relative absolute error

28.5883
Root relative squared error

$\%$

Total Number of Instances

59.8353

175

Berdasarkan nilai classifier output pada WEKA didapatkan nilai akurasi sebesar $80 \%$, dimana dari total data ujicoba sebanyak 175 data memiliki jumlah klasifikasi yang benar sebanyak 140 data sedangkan jumlah klasifikasi yang salah sebanyak 35 data. Jumlah akurasi data ini juga dapat terlihat setelah data diuji dengan teknik supplied test set pada classifier output di WEKA dan pengujian pada sistem pakar seperti yang terlihat pada Tabel 3.

\section{Hasil dan Pembahasan}

Hasil dari penelitian ini adalah sebuah sistem pakar yang digunakan untuk mengidentifikasi modalitas belajar Siswa. Sistem pakar yang dihasilkan ini memiliki sebuah lingkungan konsultasi (consultation environment) (Turban, 1995). Lingkungan konsultasi pada antarmuka yang terdapat pada sistem pakar ini terdiri dari dua sesi, yaitu sesi konsultasi dan sesi hasil konsultasi. Sesi konsultasi merupakan sesi dimana Siswa menjawab pertanyaan yang telah disediakan oleh sistem sedangkan sesi hasil konsultasi adalah hasil pengolahan data berupa identifikasi modalitas Siswa serta informasi dan saran yang diberikan kepada Siswa terkait modalitas yang dimilikinya.

Identifikasi modalitas Siswa digunakan untuk mengetahui modalitas yang dimiliki oleh Siswa untuk mengoptimalkan cara belajar agar mendapatkan hasil belajar yang memuaskan.

Tabel 3. Tabel validitas nilai akurasi dengan supplied test set dan sistem pakar

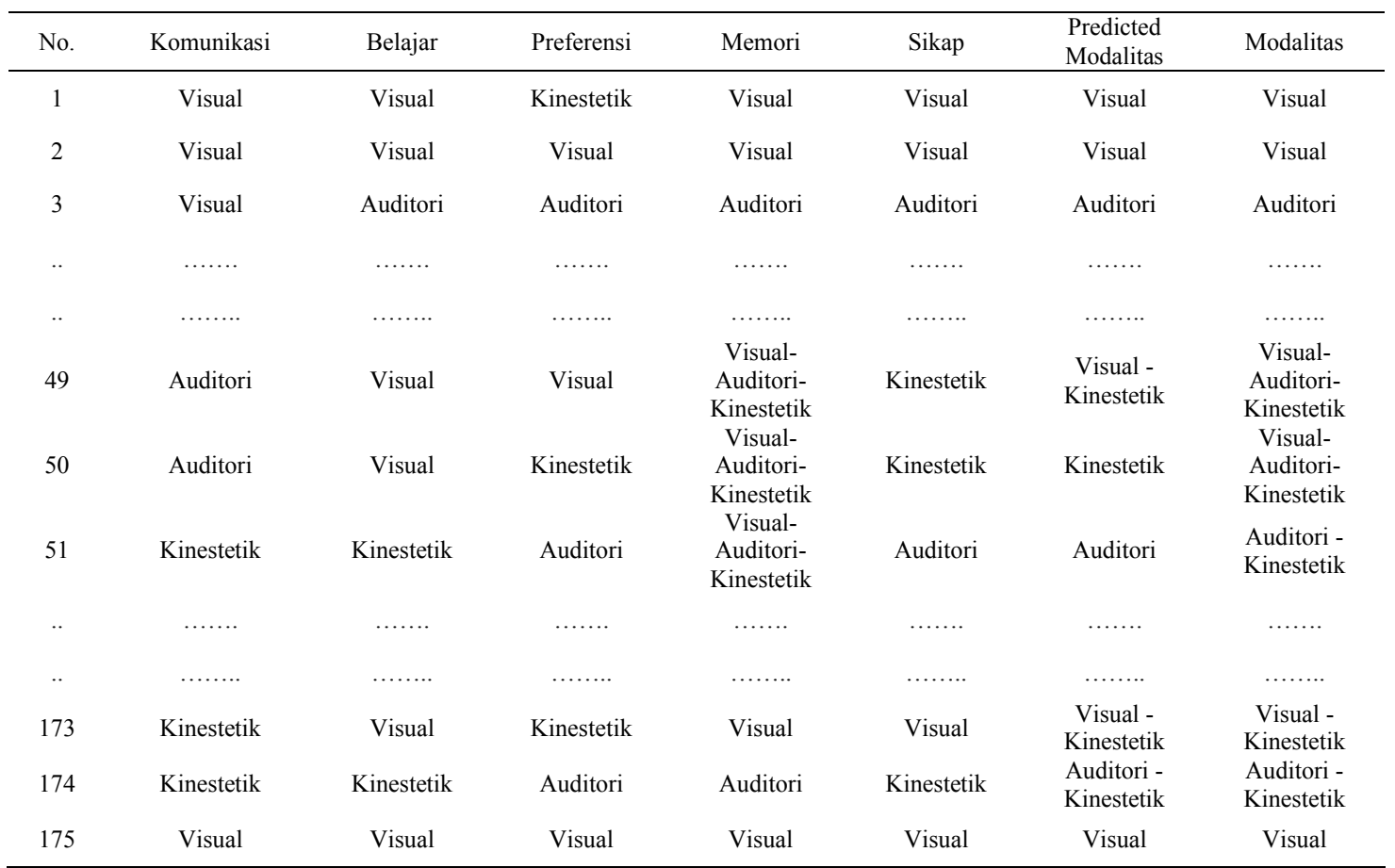


Kuesioner ini melibatkan pertanyaan yang terbagi menjadi lima kategori, yaitu kategori komunikasi, belajar, preferensi, memori dan sikap. Setiap kategori terdiri dari enam pertanyaan dengan dua pertanyaan untuk modalitas visual, dua pertanyaan untuk modalitas auditori dan dua pertanyaan lainnya untuk modalitas kinestetik. Jawaban yang diberikan merupakan jawaban opsional yang terdiri dari ya dan tidak. Pertanyaanpertanyaan dalam kuesioner yang diberikan kepada Siswa merupakan sesi konsultasi pada sistem pakar sedangkan hasil yang didapat dari proses identifikasi setelah Siswa menjawab semua pertanyaan dan menekan tombol simpan merupakan sesi hasil konsultasi.

\section{Kesimpulan}

Sistem pakar identifikasi modalitas belajar siswa dengan implementasi Algoritma C4.5 menghasilkan nilai akurasi klasifikasi sebesar $80 \%$ dan modalitas yang dapat diidentifikasi tidak hanya terbagi menjadi enam kategori saja namun menjadi tujuh kategori yaitu, visual, auditori, kinestetik, visual-auditori, visual-kinestetik, auditori-kinestetik dan visualauditori-kinestetik.

Kemampuan teknik klasifikasi data mining, yaitu pohon keputusan dengan menggunakan model Algoritma C4.5 sangat baik dalam menangani data yang memiliki atribut yang bersifat kategoris, dimana data-data ini memiliki besaran nominal yang tidak dapat dijumlahkan ataupun dikurangkan.

Pada umumnya pohon keputusan lebih banyak digunakan untuk kasus-kasus pada data diskrit dan data binary yang memiliki keluaran hanya terdiri dari dua kelas. Namun, pada kasus penelitian ini memiliki kelas pada target atribut sebagai keluaran lebih dari dua dan pohon keputusan dengan model Algoritma C4.5 masih dapat memberikan solusi yang baik.

Pohon keputusan dengan model Algoritma C4.5 merupakan salah satu metode belajar (learning) yang sangat populer dan dapat digunakan secara praktis seperti halnya dalam penelitian ini. Namun selain pohon keputusan ini masih ada metode belajar yang dapat digunakan untuk menemukan himpunan aturan (rule) yang optimal seperti Jaringan Syaraf Tiruan (JST) dan Algoritma Genetika (AG). Hal ini tidak menutup kemungkinan untuk dapat diimplementasikan pada sistem pakar.

\section{Daftar Pustaka}

Abraham, Ajith, 2004. Rule-based Expert Systems. Handbook of Measuring System Design. Oklahoma State University, Stillwater, USA.

Andujar, G.J.L., Quintanilla, C.F., Izquierdo, J., and Urbano, J.M., 2006. SIMCE : An expert system for seedling weed identification in cereals.
Computers and Electronics in Agriculture. 06115-123

Bramer, M., 2007. Principles Of Data Mining. Undergraduate Topics In Computer Science Springer, London.

DePorter, B. and Hernacki, M., 1999. Quantum Learning: Membiasakan Belajar Nyaman dan Menyenangkan. (terjemahan Alwiyah Abdurrahman). Bandung: Kaifa (Buku asli diterbitkan tahun 1992).

Firebaugh, M.W., 1989. Artificial Intelligence: A Knowledge-based Approach. Boston : PWSRENT Publishing Company.

Grassle, P., Baumann, H. and Baumann, P., 2005. UML 2.0 In Action : A Project-Based Tutorial. Brimingham : Packt Publishing Ltd.

Iuera, C., Neacşu, I., Safta, C.G. and Suditu, G.M., 2011. The Study of the Relation between the Teaching Methods and the Learning Styles - The Impact upon the Students' Academic Conduct. Proceeding Social and Behavioral Sciences, 11 256-260

Kaloudis, S., Anastopoulos, D., Yialouris, C.P., Lorentzos, N.A., and Sideridis, A.B., 2005. Insect identification expert system for forest protection. Expert Systems with Applications 28 445-452

Kasmawi, 2013. Rancang Bangun Sistem Informasi Evaluasi Usability Website Di Perguruan Tinggi, Tesis, Magister Sistem Informasi, Universitas Diponegoro, Semarang.

Kusumadewi, S., 2003, Artificial Intelligence, Teknik dan Aplikasinya. Yogyakarta : Graha Ilmu.

Larose, Daniel T., 2005. Discovering Knowledge in Data : An Introduction to Data Mining. London : John Willey \& Sons, Inc.

Li, D., Fu, Z., and Duan, Y., 2002. Fish expert : a web-based expert system for fish disease diagnosis. Expert Systems with Applications 23 311-320.

Moertini, V.S., 2005. Towards Classifying Classical Batik Images, Proc. of Intl. Conference on Information and Communication Technology, UMB, Jakarta.

Othman, N., and Amiruddin, M.H., 2010. Different Perspectives of Learning Styles from VARK Model. Proceeding Social and Behavioral Sciences, 7 - 652-660

Papic',V., Rogulj, N., and Pleština, V., 2009. Identification of sport talents using a weboriented expert system with a fuzzy module. Expert Systems with Applications 36: 8830-8838

Prasadl, B.D.C.N., Prasad, K.P.E.S.N., and Sagar, Y., 2011. An approach to develop expert system in medical diagnosis using machine learning algorithms (asthma) and a performance study. International Journal on Soft Computing (IJSC), Vol.2, No. 1, February 2011. 
Quinlan, J.R.., 1993. C4.5 : Programs for machine learning. Morgan Kaufmann, San Francisco.

Raditya, A., 2012. Implementasi data mining classification untuk mencari pola prediksi hujan dengan menggunakan algoritma C4.5, Skripsi, Fakultas Teknologi Industri, Universitas Gunadarma, Depok.

Sari, N.P., 2013. Pengaruh gaya belajar siswa terhadap prestasi belajar matematika siswa. empathy Jurnal Psikologi, Universitas Ahmad Dahlan, Vol.2, No.1, Juli 2013.

Spiegel, R., and Nenh, Y. P., 2004. An expert system supporting diagnosis in clinical psychology. Human Perspectives in the Internet Society: Culture, Psychology and Gender 2004 WIT Press.

Suyanto, 2009. Artificial Intelligence : Searching, Reasoning, Plannning, Learning . Informatika : Bandung.
Suyanto, 2011. Artificial Intelligence: Searching, Reasoning, Plannning, Learning (Edisi Revisi) . Informatika : Bandung.

Tomuletiu, E.A., Monica, F., Mihaela, S., Brindusa, G., Maria, S.A., and Adela, M., 2011. The relation between pupils' learning style and educational performance. Proceeding Social and Behavioral Sciences 11- 1502-1506

Turban, E., 1995. Decision Support and Expert System. Management Support System. Newyork: Prentice-Hall.

Winkel, W.S., 2007. Psikologi Pengajaran. Grasindo Persada : Jakarta.

Wu, L.C., Lee, J.X., Huang H.C., Liu, B.J., and Horng, J.T., 2009. An expert to predict protein thermostability using decision tree. Expert Systems with Applications, 09- 9007-9014 